\title{
Habitat selection by grey mullets (Osteichthyes: Mugilidae) in Mediterranean estuaries: the role of salinity
}

\author{
LUIS CARDONA \\ Department of Experimental and Health Sciences, Faculty of Biology, University Pompeu Fabra, Avda. Dr. Aiguader 80, \\ E-08003 Barcelona, Spain.
}

\begin{abstract}
SUMMARY: A stratified study of microhabitat use by grey mullet on the island of Minorca (Balearic archipelago, western Mediterranean) showed that the distribution of all the species was dramatically affected by salinity. Sites with a salinity level under 15 were positively selected in spring and summer by those species whose growth performance was the best in oligomesohaline water (Liza ramado and Mugil cephalus) but also by a species whose growth was not affected by salinity (Chelon labrosus). Liza aurata concentrated in polyhaline and euhaline sites, where growth was improved, a pattern also exhibited by Liza saliens. Both species avoided fresh water sites all year round. As a consequence, community structure was correlated with salinity. The above reported electivity patterns often disappeared in autumn, when most grey mullets migrate off-shore.
\end{abstract}

Keywords: Chelon labrosus, Liza aurata, Liza ramado, Liza saliens, Mugil cephalus, salinity.

RESUMEN: SELECCIÓN DEL HÁBITAT POR LOS MUGílidos (OsTeichthyes: MugILIDAE) EN LOS ESTUARIOS MEdITERRÁNEOS: EL PAPEL DE LA SALINIDAD.. - Se ha realizado un estudio estratificado sobre el uso del hábitat por parte de los mugílidos en Menorca (Islas Baleares, Mediterráneo occidental). El análisis de los datos ha revelado la importancia de la salinidad para explicar la distribución de las cinco especies de mugílidos presentes en los estuarios mediterráneos. Las zonas con una salinidad inferior a 15 fueron seleccionadas positivamente en primavera y verano por aquellas especies cuyo crecimiento se maximiza en aguas oligomesohalinas (Liza ramado y Mugil cephalus), e incluso por una especie cuyo crecimiento no se ve afectado por la salinidad (Chelon labrosus). Liza aurata se concentró durante todo el año en lugares con una salinidad polihalina o euhalina, ya que su crecimiento se maximiza en dicho rango. El mismo patrón de distribución se observó para Liza saliens. Ambas especies evitaron los ambientes dulceacuícolas durante todo el año. Como consecuencia de lo anterior, la estructura de las comunidades de mugílidos durante la primavera y el verano está relacionada con la salinidad. Los patrones de electividad arriba descritos desaparecieron con frecuencia en otoño, cuando una fracción importante de la población de todas las especies emigra al mar.

Palabras clave: Chelon labrosus, Liza aurata, Liza ramado, Liza saliens, Mugil cephalus, salinidad.

\section{INTRODUCTION}

Grey mullet (Osteichthyes, Mugilidae) commonly inhabit tropical and warm-temperate estuaries (McDowall, 1988; Blaber, 1997; Pombo et al., 2005), where they play a crucial ecological role (Laffaille et al., 1998, 2002; Torras et al., 2000; Cardona et al., 2001; Almeida, 2003) and usually support artisanal fisheries (McDowall, 1988; Blaber, 1997). Although these species always spawn at sea, they are highly euryhaline and thrive in a wide range of salinities (McDowall, 1988). Due to their euryhalinity, they are often stocked in brackish coastal lagoons to improve fish yield (Ravagnan, 1992) and are introduced into fresh water lakes and reservoirs to create new fisheries (Ben Tuvia et al., 1992). In 
spite of the ecological and economical importance of grey mullet, proper management is hindered by the lack of information on habitat selection.

Growth of euryhaline species is often affected by salinity because the energy used for osmoregulation is not available for growth (Brett, 1979; Wootton, 1990). Consequently, many of these species have an optimum salinity level at which the growth rate is highest and the cost of osmoregulation lowest, which may affect fish distribution in the wild (Blaber, 1997). Laboratory experiments revealed distinct osmoregulatory strategies among European grey mullet species (Vallet et al.,, 1970; Lassere and Gallis, 1975; Nordlie and Leffler, 1975; Nordlie et al., 1982; Kulikova et al.,, 1989; Shusmin, 1990; Cardona, 2000), indicating that there are differential distribution patterns along salinity gradients in the wild. However, detailed information about habitat use by European grey mullet species is only available for one species (Cardona, 2000), although tolerance ranges are known for others (Faouzi, 1938; Heldt, 1948; De Angelis, 1967; Paris and Quignard, 1971). In this paper we evaluate the relevance of salinity for explaining the distribution of grey mullet species in Mediterranean estuaries and also whether this environmental factor is a useful predictor of assemblage structure.

\section{MATERIAL AND METHODS}

Habitat selection was studied on the island of Minorca (Balearic archipelago, western Mediterranean), following Baltz's (1990) procedures for stratified studies on microhabitat use. Samples were collected in four seasons (November 1991, February 1992, May 1992 and July 1992) at thirteen points in the nine major estuaries of the island (Es Gorg, Albufera d'es Grau, es Mercadal, Binimel.là, Algaiarens, Algendar, Trebelúger, Son Bou, and Cala en Porter). Sampling stations were selected depending on salinity. When an estuary showed a salinity gradient, the number of sampling stations was at least as high as the number of salinity ranges recorded in that estuary and season (see below for salinity classification).

Salinity was measured with a hand refractometer and expressed with the Practical Salinity Scale. Water samples were collected at one-metre intervals along the water column. The first sample was always collected at the surface and the final sample at the bottom. This methodology allowed us to study water stratification and calculate the average salinity of the water column at each point. The area is tide-free therefore salinity did not change during the day. The Venice Conference salinity scale (Anonymous, 1959), although slightly modified in agreement with Bulger et al., (1993), was used to establish five salinity ranges: fresh water for values below 1.0, oligohaline between 1.1 and 5.0, mesohaline between 5.1 and 15.0, polyhaline between 15.1 and 30.0 and euhaline between 30.1 and 40.0.

A trammel net with a length of 45 metres, a depth of 1.5 metres and a stretched mesh size of 25 millimetres was laid for 24 hours. These nets were used because they are less selective than gill nets (Perrow et al.,, 1996) and this mesh size caught grey mullet with total lengths between 70 and 542 millimetres. Each site was sampled on two or three days every season.

Sampling effort was uneven, being more intense in the smaller estuaries. Hence, weighting factors were used to calculate the theoretical catch obtained if effort had been uniform (Baltz, 1990). The surface of each estuary was measured using the maps provided by the Insular Council of Minorca (1:5000), corrected by field observations carried out during the surveys. The available surface of each microhabitat on the whole island was calculated by adding that present in each estuary. Once habitat had been mapped, weighting factors were calculated as the quotient between the number of fishing units needed to sample each habitat type in each estuary with an effort level of one fishing unit per hectare and the true number of fishing units used. True catch was multiplied by this factor to obtain the theoretical catch for each kind of habitat and estuary, and hence calculate the theoretical distribution of the population.

The mouths of Albufera d'es Grau, es Mercadal, Binimel.là, Algaiarens, Trebelúger, and Son Bou estuaries were closed by a sand bar throughout the dry season (from April to October) and hence fish exchange with the sea did not occur. Consequently, the spring and summer abundance of grey mullets in these blind estuaries is thought to reflect microhabitat selection just before the closure of the mouth and perhaps differential mortality throughout the landlocking period. Thus, habitat availability in May and July was computed as a combination of the actual availability in open estuaries and that in blind estuaries just before mouth closure. 


\section{Statistics}

In agreement with the ideal free distribution theory (Ranta et al.,, 1999), the null hypothesis was that fish distribution reflects habitat availability. Therefore, the chi-square test (Cuadras, 1983) was used for a global comparison of availability and habitat use (Neu et al.,, 1974). The values expected were the percentages of surface available of each microhabitat type and the values observed were the percentages of the population inhabiting each microhabitat type. When significant differences were detected, the preference for avoidance of or indifference to each habitat type was measured using Ivlev's electivity index (1961, quoted by Baltz, 1990): $\mathrm{I}=\left(\mathrm{p}_{\mathrm{p}}-\mathrm{p}_{\mathrm{h}}\right) /\left(\mathrm{p}_{\mathrm{h}}+\mathrm{p}_{\mathrm{p}}\right)$ where $\mathrm{p}_{\mathrm{p}}$ is the percentage of the population in that microhabitat and $\mathrm{p}_{\mathrm{h}}$ is the relative abundance (percentage) of that kind of habitat. The confidence intervals of the electivity estimates were calculated using Strauss's equation (1979):

$$
\begin{gathered}
E_{c}=\left(2-\left(\frac{2 p_{e}}{\left(p_{e}+p_{t}\right)}\right)\right) \times \\
\times\left[1 \pm 1.96 \sqrt{\left[2 n_{t} * p_{t} *\left(1-p_{e}\right) *\left(p_{t}+p_{e}\right)^{2}+p_{t} *\left(1-p_{t}\right) * n_{e}+p_{e} * \frac{\left(1-p_{e}\right)}{n_{t} n_{e}\left(p_{t}+p_{e}\right)^{2}}\right]}\right]-1
\end{gathered}
$$

where $E_{c}$ are the limits of the $95 \%$ confidence interval, $n_{t}$ is the size of the fish sample, $n_{e}$ is the size of the habitat sample, $p_{t}$ is the percentage of the population at that salinity, $\mathrm{p}_{\mathrm{e}}$ is the percentage of the habitat with that salinity, $\mathrm{z}$ is 1.96 , i.e. the 2 -sided normal deviate at significance level $\mathrm{a}=0.05$.

Following Legendre and Legendre (1998), an indirect gradient analysis was used to assess the role of salinity in assemblage organisation. Catch per unit effort data (number of fish caught per $\mathrm{m}^{2}$ of net and hour of fishing) was first log-transformed $(y=\log$ $(\mathrm{x}+1)$ and then Principal Component Analysis (PCA) was applied to ordinate assemblages in a reduced space. In a second step, Kendall's t rank correlation (Cuadras, 1983) between the position of the assemblages along each of the two major axes extracted by PCA and salinity was calculated. Calculations were performed with the SPSS.11 package.

\section{RESULTS}

The estuaries considered had a total of 101 hectares of open water suitable for grey mullet. Some adjoining temporary wetlands flooded in the
TABLE 1. - Habitat availability in the estuaries of Minorca (\%), when divided into five salinity levels. Total surface was 101 ha all year round.

salinity freshwater oligohaline mesohaline polyhaline euhaline

\begin{tabular}{lccccc}
\hline Autumn & 6.3 & 4.5 & 2.0 & 85.4 & 1.8 \\
Winter & 2.3 & 8.4 & 16.3 & 73.0 & 0.0 \\
Spring & 2.3 & 12.3 & 2.5 & 73.0 & 9.9 \\
Summer & 0.3 & 14.3 & 2.5 & 79.9 & 3.0
\end{tabular}

rainy season but were never visited by fish because they were very shallow (depth $<20$ centimetres). Consequently, the surface of open water available for fish did not change throughout the year. Salinity gradients usually occurred only in estuary mouths and hence only one salinity range was present in most. However, salinity gradients were detected along the Es Gorg, Albufera d'es Grau and es Mercadal estuaries and several sampling stations were established there.

Most of the available estuarine habitat was polyhaline all year round (Table 1) because of the large extension of the Albufera d'es Grau estuary. The availability of fresh water habitats increased in autumn, decreased in winter and spring and dropped in summer, because of seasonal differences in rainfall. The availability of oligohaline and mesohaline habitats also fluctuated seasonally, but the availability of polyhaline habitats remained at similar levels throughout the year. Euhaline habitats only occurred in open estuaries (Es Gorg and Algendar).

5598 specimens were collected: 458 golden grey mullet Liza aurata (Risso, 1810), 1147 thinlip mullet Liza ramado (Risso, 1810), 2065 leaping mullet Liza saliens (Risso, 1810), 396 flathead mullet Mugil cephalus L, 1758 and 1532 thicklip mullet Chelon labrosus (Cuvier 1829).

The total length of L. aurata ranged between 111 and 290 millimetres (Fig. 1), but only two specimens were longer than $271 \mathrm{~mm}$ and hence may be considered adults in agreement with Brusle (1981). The population concentrated in polyhaline sites during most of the year, although occurrence in euhaline sites increased in spring and summer (Fig. 2). The Chi-square test indicated that distribution was unrelated to habitat availability (d.f. $=5$ in February and 7 in the other seasons; $\mathrm{P}<0.05$ for all seasons). Sites with a salinity level lower than 15 were avoided all year round, although a few specimens were found in freshwater in autumn.

L. ramado ranged between 124 and 452 millimetres in total length. Specimens with a total length over 

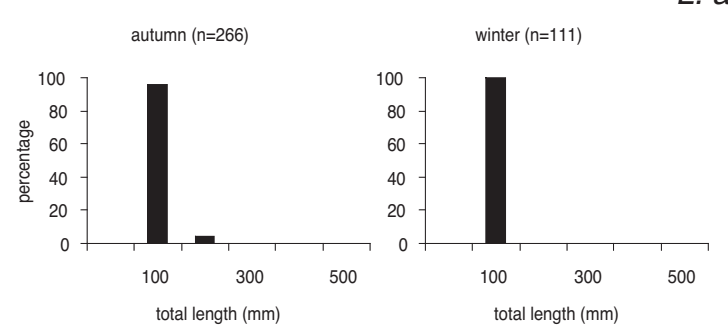

\section{L. aurata}

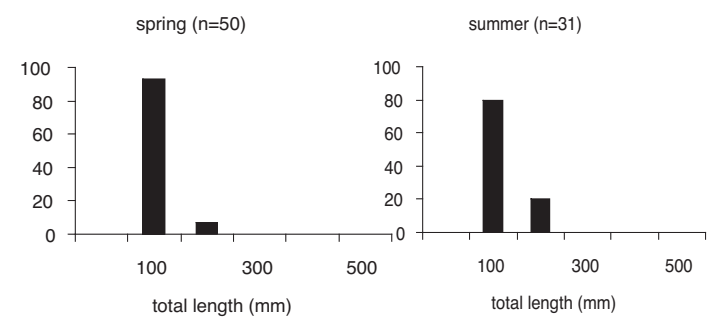

\section{L. ramado}
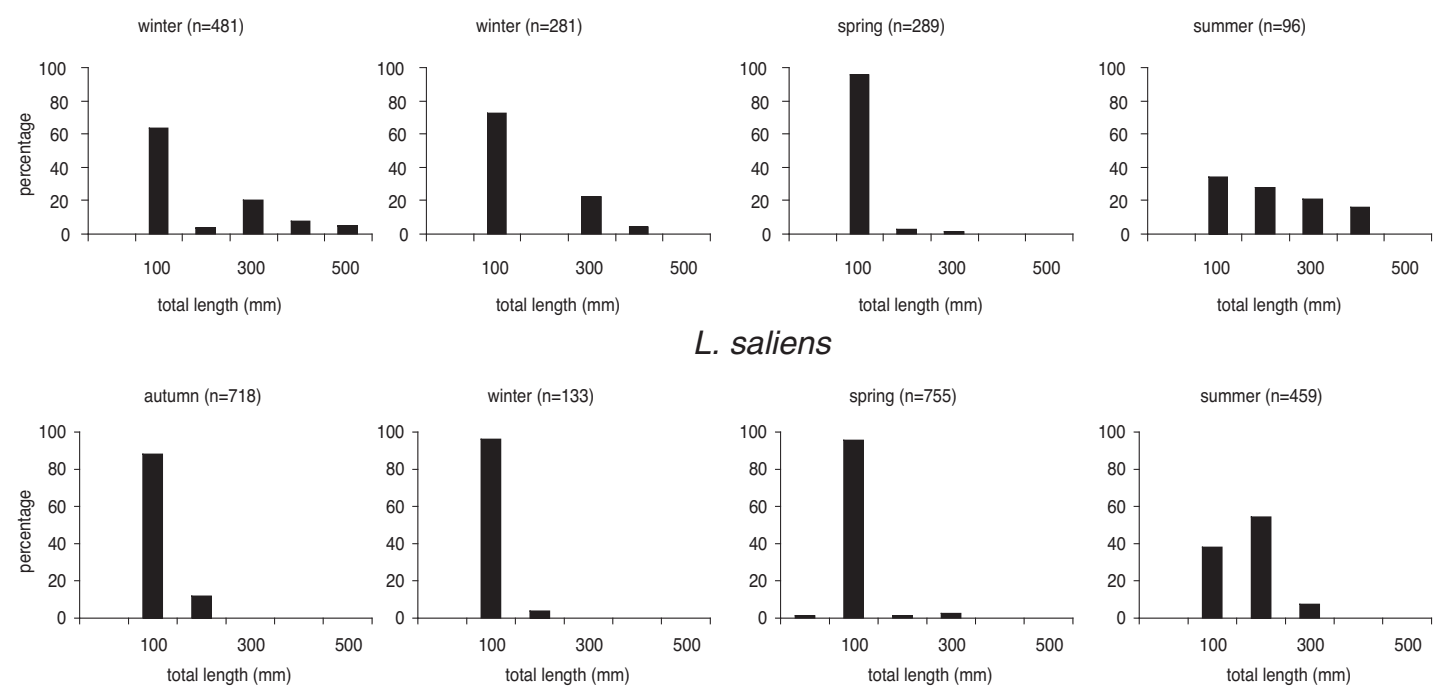

\section{M. cephalus}
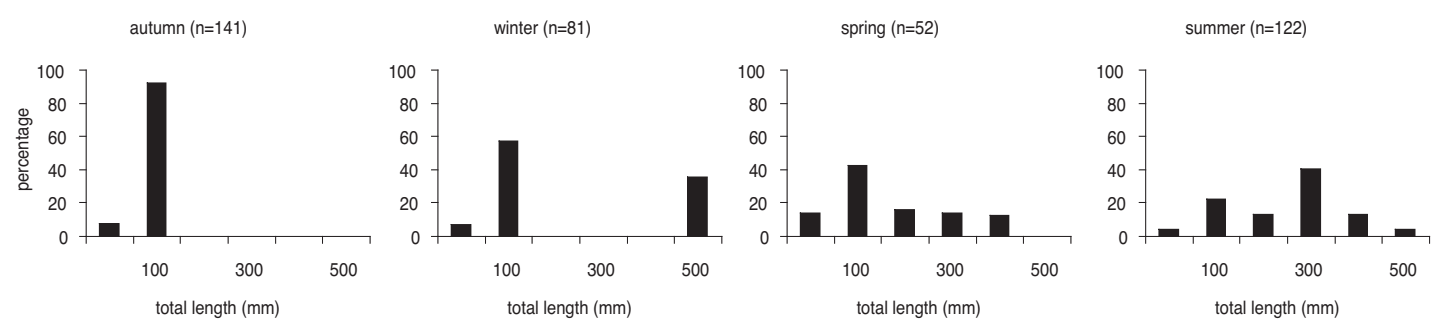

\section{C. labrosus}
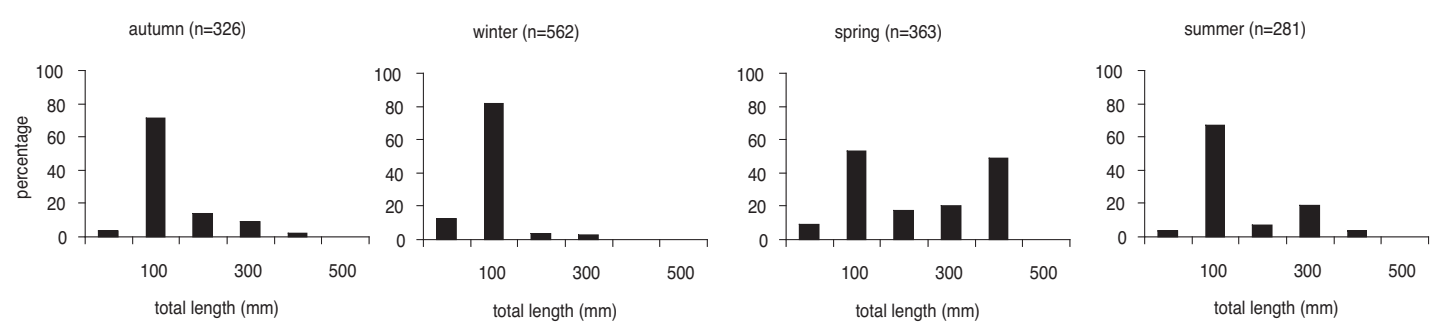

FIG. 1. - Seasonal length-frequency plots of L. aurata, L. ramado, L. saliens, M. cephalus and C. labrosus.

301 millimetres were considered adults in agreement with Brusle (1981) and shared the sampled sites with juveniles all year round (Fig. 1). The population concentrated in polyhaline sites throughout most of the year, although use of less saline environments increased in winter (Fig. 3). However, the Chi-square test indicated that distribution was unrelated to habitat availability (d.f. $=5$ in winter and 7 in the other seasons; $\mathrm{P}<0.05$ for all seasons). The electivity of sites within the freshwater and oligohaline ranges was positive or neutral from winter to summer, but not in autumn. The use of mesohaline sites matched avail- 


\section{Autumn $(n=266)$}
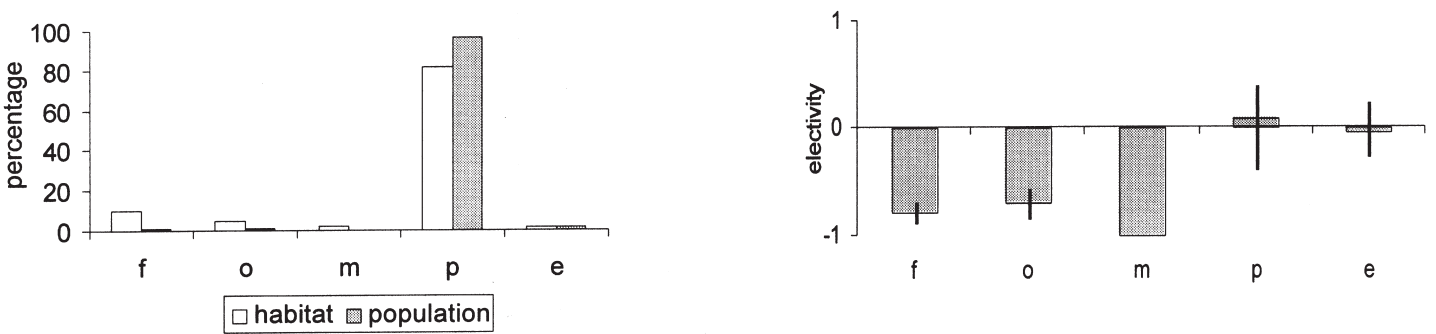

Winter $(n=111)$
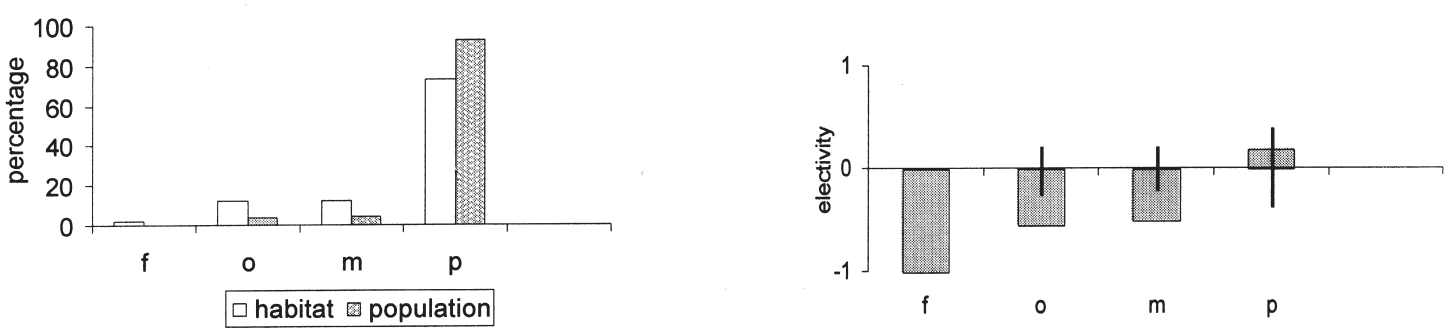

Spring $(n=50)$
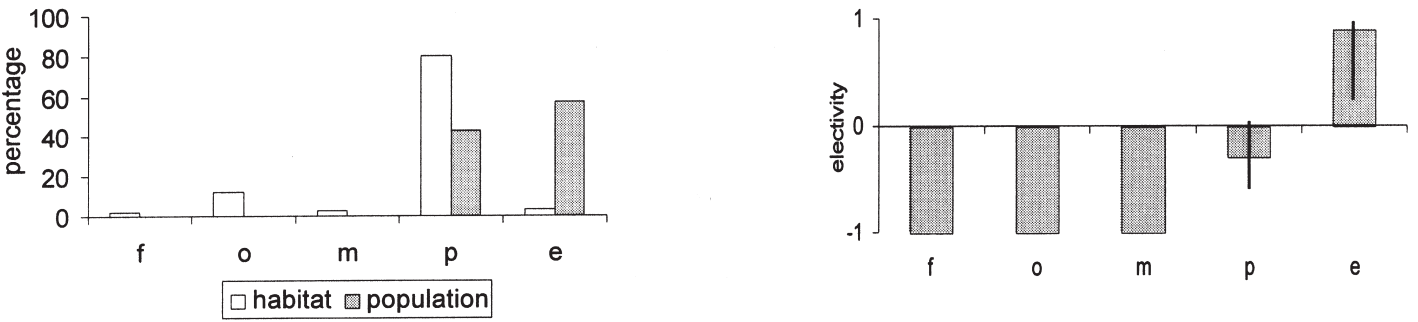

Summer $(n=31)$
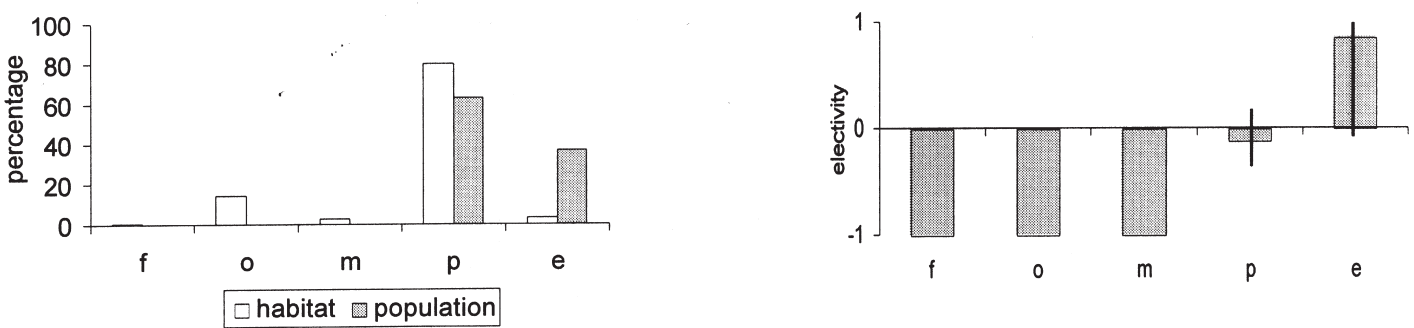

FIG. 2. - Electivity of habitat types by L. aurata. The left column shows fish distribution in the five habitat types (f : freshwater, o : oligohaline, $\mathrm{m}$ : mesohaline, $\mathrm{p}$ : polyhaline, e : euhaline). The right column shows the electivity plots. The number in brackets is the sample size and the vertical bars show the $95 \%$ confidence intervals. In both columns, a missing initial for a habitat type denotes that it was not present in that season.

ability all year round. Euhaline sites were strongly avoided throughout the year, except in November when they were positively selected.

L. saliens ranged between 105 and 285 millimetres in total length. Adult specimens, with a total length over 171 millimetres (Brusle 1981), were found all year round, but their relative abundance increased dramatically in summer (Fig. 1). The population concentrated in polyhaline sites, the most abundant habitat type, throughout the year (Fig. 4), but the Chi-square test indicated that distribution was unrelated to habitat availability (d.f. $=5$ in 


\section{Autumn ( $n=481)$}
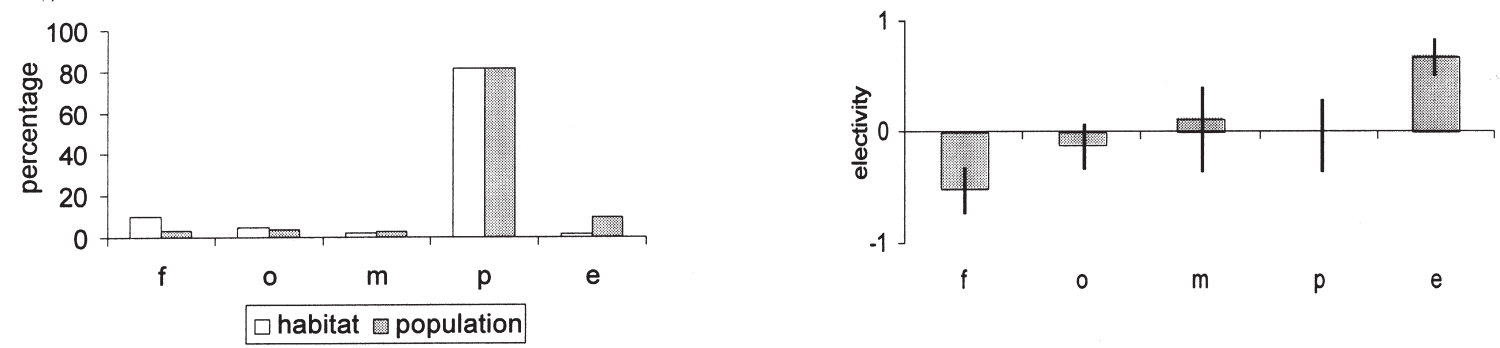

Winter $(n=281)$
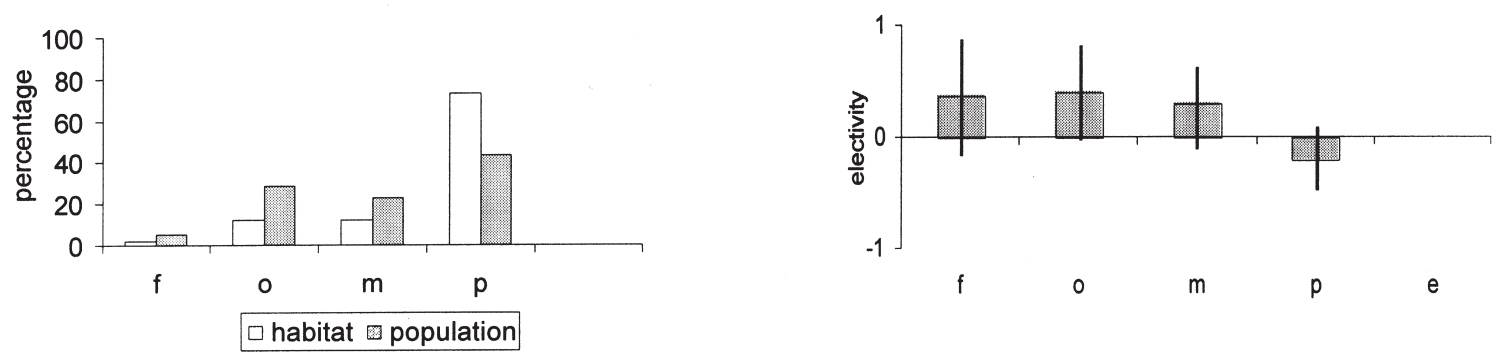

Spring $(n=289)$
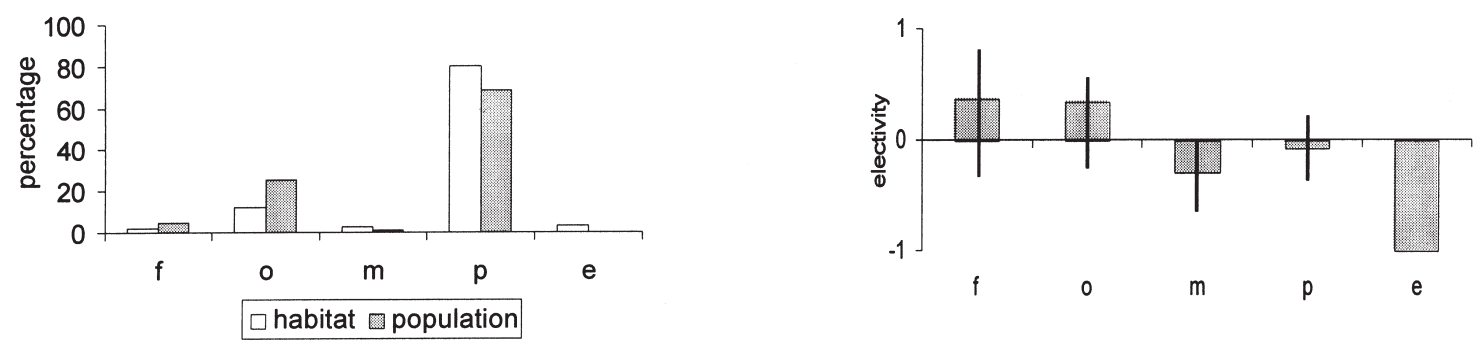

Summer $(n=96)$
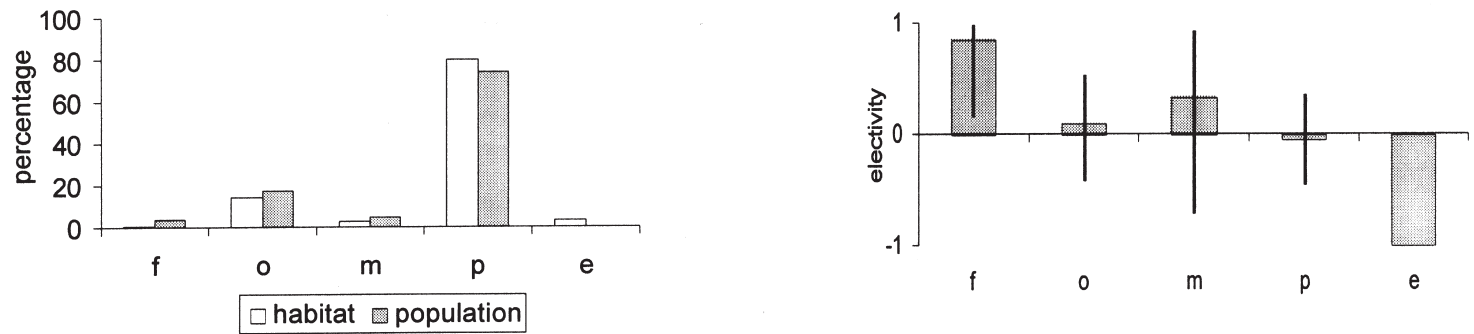

FIG. 3. - Electivity of habitat types by L. ramado. The left column shows fish distribution in the five habitat types (f: freshwater, o: oligohaline, m: mesohaline, p: polyhaline, e: euhaline). The right column shows the electivity plots. The number in brackets is the sample size and the vertical bars show the $95 \%$ confidence intervals. In both columns, a missing initial for a habitat type denotes that it was not present in that season.

February and 7 in the other seasons; $\mathrm{P}<0.05$ for all seasons). Euhaline sites were positively selected in autumn, whereas oligohaline, mesohaline and polyhaline were used depending on availability and freshwater sites were avoided. In winter, use of brackish habitat types matched availability, but fresh water zones were avoided. Freshwater, oligohaline and mesohaline sites were strongly avoided in spring and summer when polyhaline sites were used in agreement with availability.

M. cephalus ranged between 87 and 542 millimetres in total length. Adult specimens, with a total 
Autumn $(n=718)$
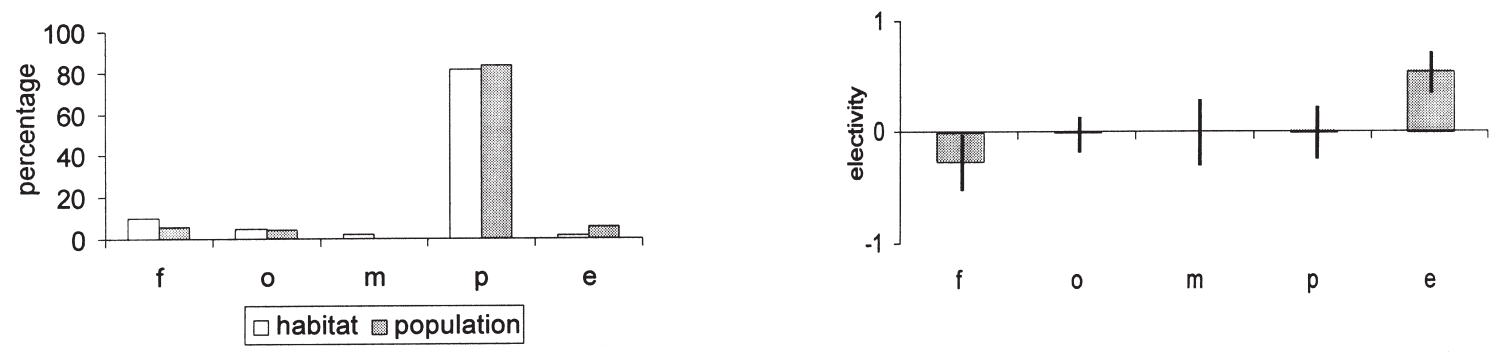

Winter $(n=133)$
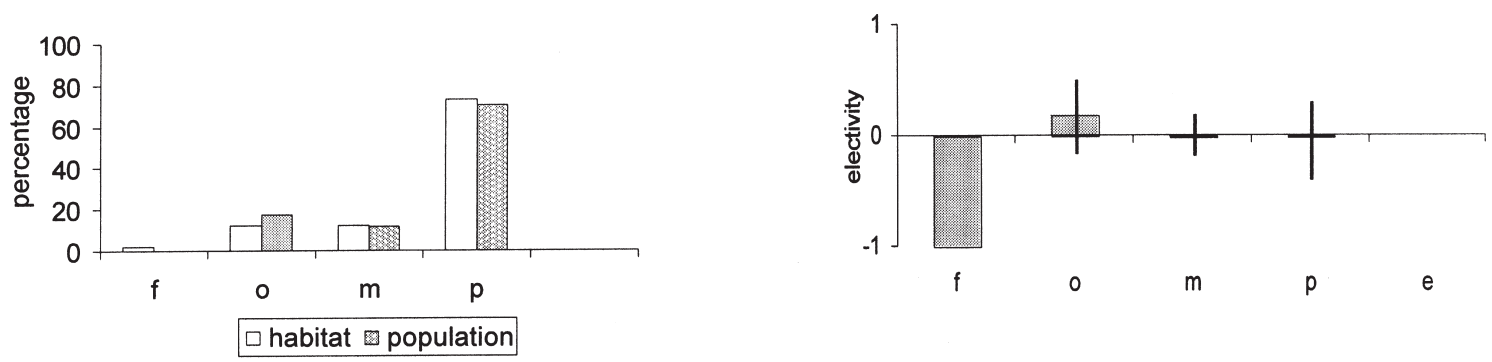

Spring $(n=755)$
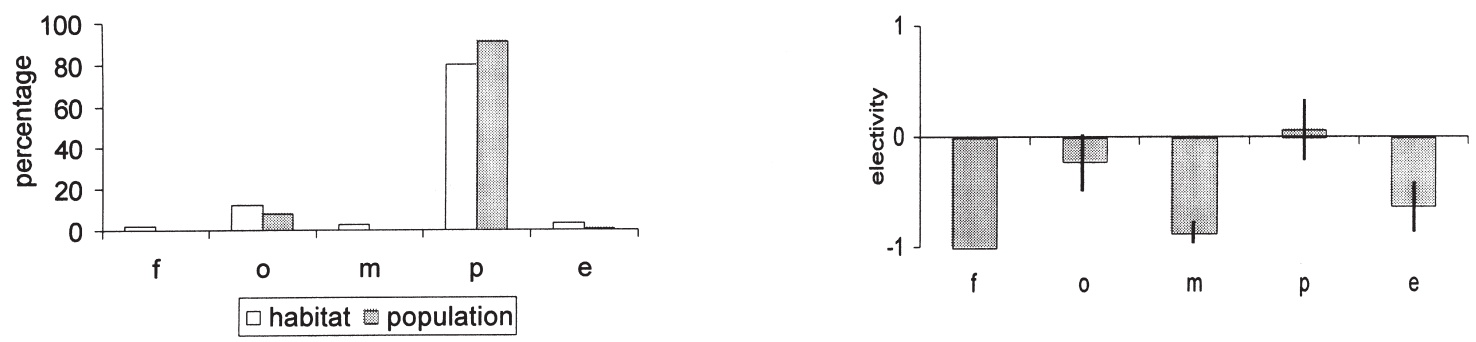

\section{Summer $(n=459)$}
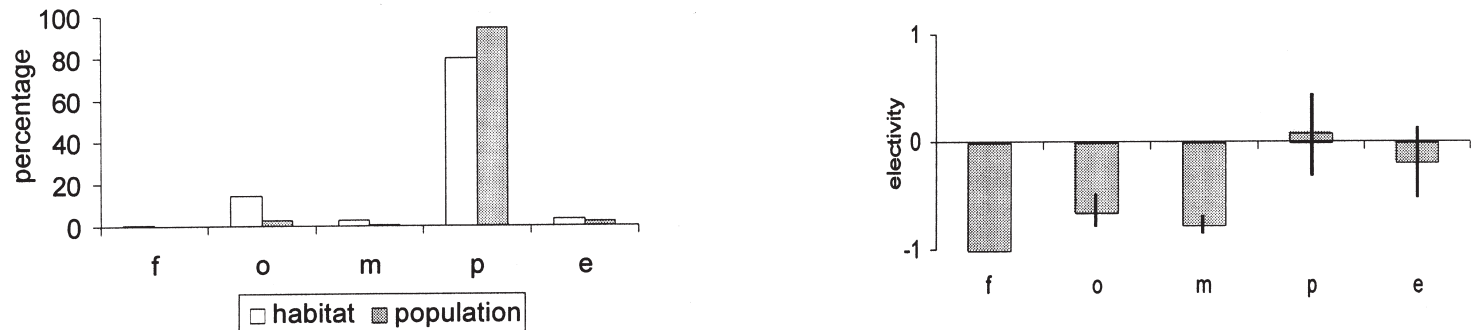

FIG. 4. - Electivity of habitat types by L. saliens. The left column shows fish distribution within the five habitat types (f: freshwater, o: oligohaline, m: mesohaline, p: polyhaline, e: euhaline). The right column shows the electivity plots. The number in brackets is the sample size and the vertical bars show the $95 \%$ confidence intervals. In both columns, a missing initial for a habitat type denotes that it was not present in that season.

length over 301 millimetres (Brusle 1981), were found all year round, but their relative abundance increased dramatically in spring and summer (Fig. 1). Usually, most of the population occurred in oligohaline and mesohaline sites, although in November most of them were found in freshwater and polyhaline areas (Fig. 5). Consequently, their distribution was unrelated to habitat availability (Chi-square test; d.f. $=5$ in February and 7 in the other seasons; $\mathrm{P}<0.05$ for all seasons). The electivity values for freshwater, oligohaline and mesohaline sites were usually neutral or positive throughout the 
Autumn ( $n=141)$
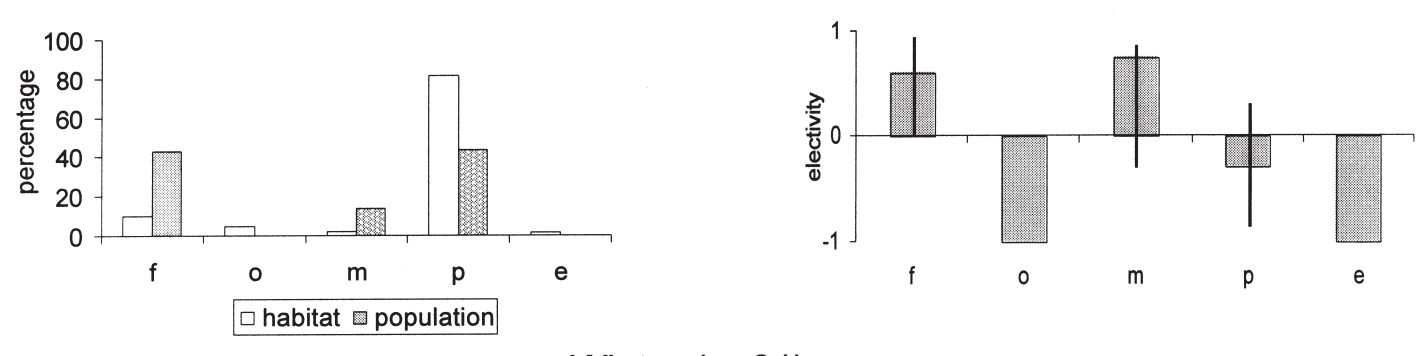

Winter $(n=81)$
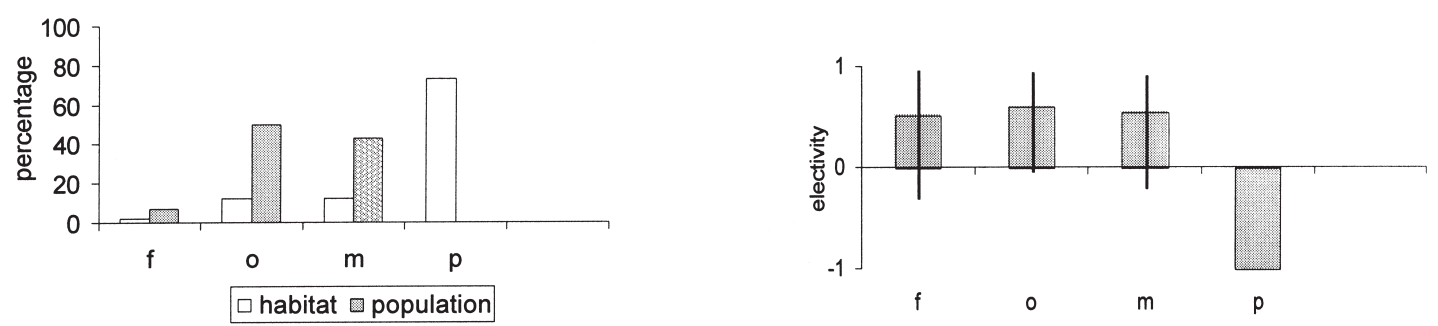

Spring $(n=52)$
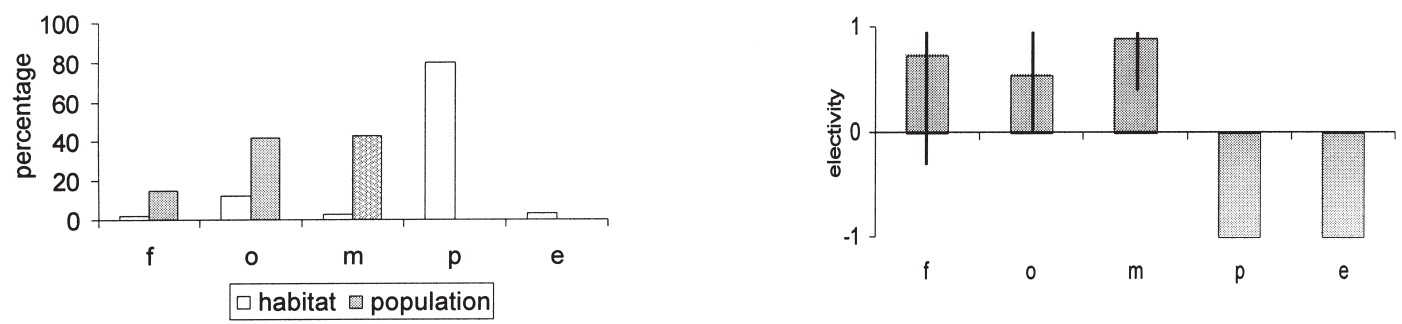

\section{Summer $(n=122)$}
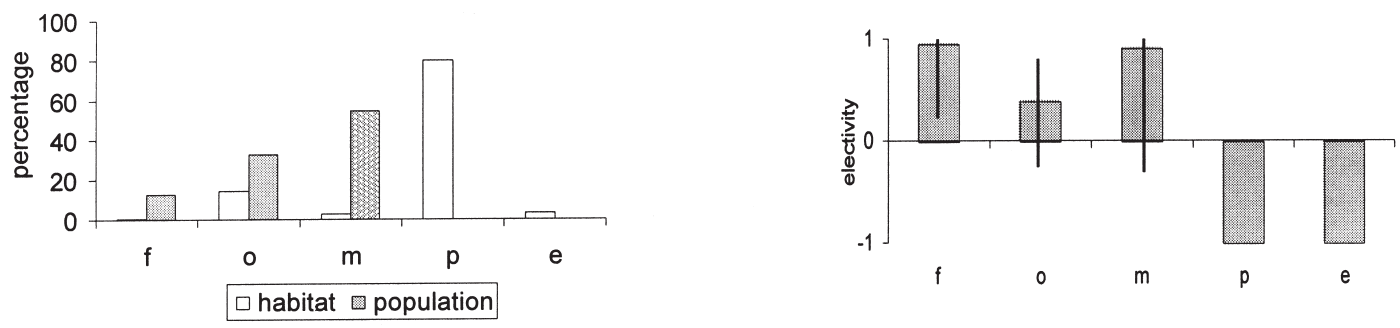

FIG. 5. - Electivity of habitat types by M. cephalus. The left column shows fish distribution in the ten habitat types (f: freshwater, o: oligohaline, m: mesohaline, p: polyhaline, e: euhaline). The right column shows the electivity plots. The number in brackets is the sample size and the vertical bars show the $95 \%$ confidence intervals. In both columns, a missing initial for a habitat type denotes that it was not present in that season.

year, whilst polyhaline and euhaline sites were always avoided.

C. labrosus ranged from 70 to 406 millimetres in total length. Adult specimens, with a total length over 301 millimetres (Brusle, 1981) were found all year round (Fig. 1). In winter and spring, most of the population was found in mesohaline and polyhaline sites, but in summer most concentrated in oligohaline sites (Fig. 1). The Chi-square test indicated that distribution was unrelated to habitat availability (d.f. $=5$ in February and 7 in the other seasons; $\mathrm{P}<0.05$ for all seasons). The electivity analysis 


\section{Autumn $(n=326)$}
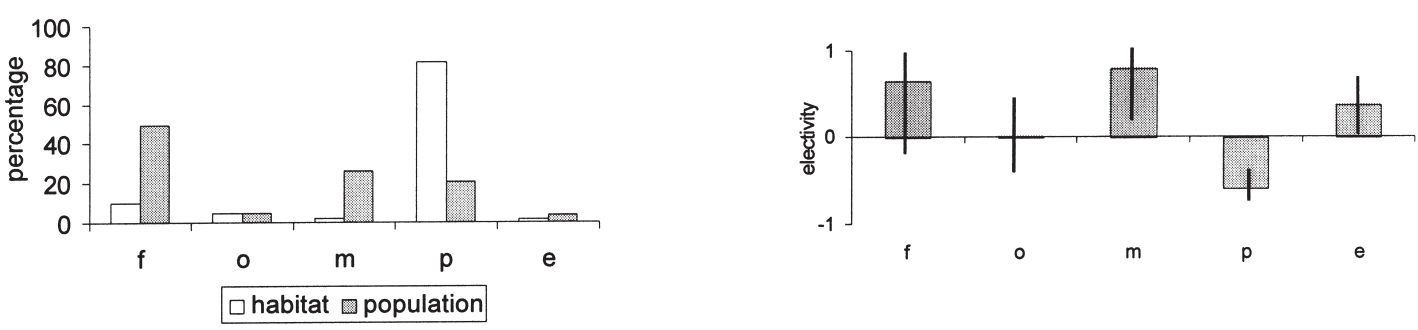

Winter $(n=562)$
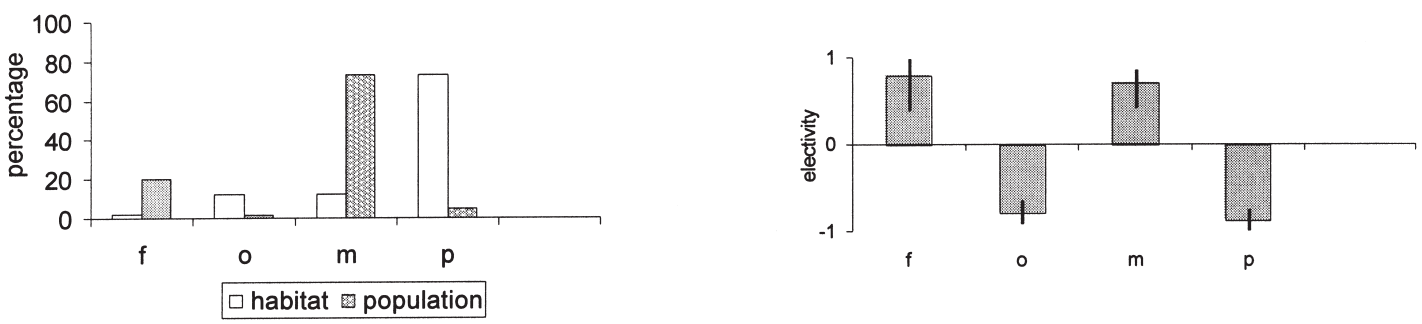

Spring $(n=363)$
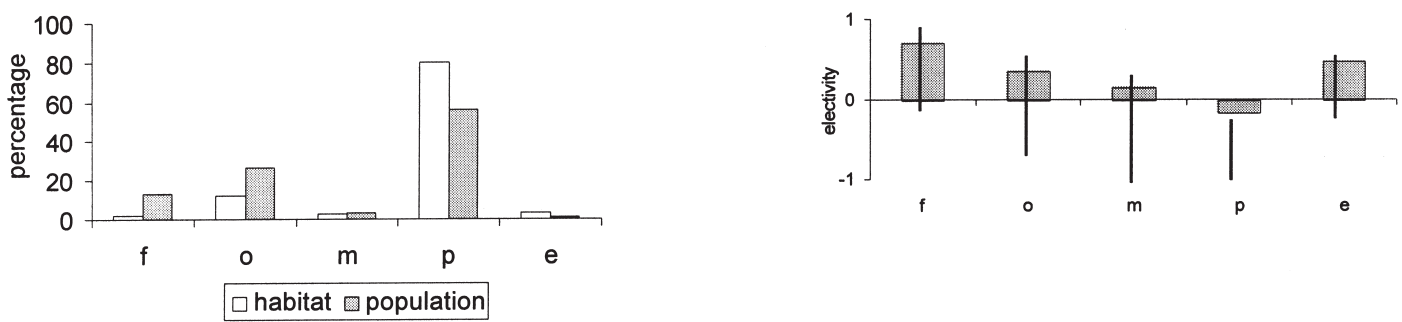

\section{Summer $(n=281)$}
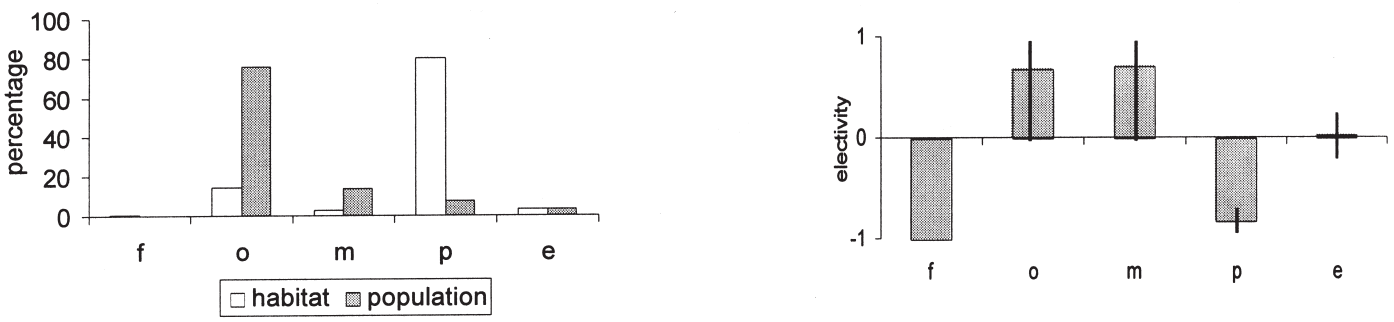

FIG. 6. - Electivity of habitat types by C. labrosus. The left column shows fish distribution in the ten habitat types (f: freshwater, o: oligohaline, m: mesohaline, p: polyhaline, e: euhaline). The right column shows the electivity plots. The number in brackets is the sample size and the vertical bars show the $95 \%$ confidence intervals. In both columns, a missing initial for a habitat type denotes that it was not present in that season.

revealed an inconsistent pattern along the salinity gradient in autumn and winter, but a strong preference for brackish sites with a salinity level lower than 15 in spring and summer. Freshwater sites were positively selected from winter to spring, but strongly avoided in summer.
In spring and summer, the first component extracted by PCA (Tables 2 and 3) opposed those species that favoured high salinity sites or used them depending on availability (L. aurata and L. saliens) to those with a strong preference for oligomesohaline sites (L. ramado and M. cephalus). 
TABLE 2. - Components extracted by PCA

\begin{tabular}{lccc}
\hline & $\begin{array}{c}\text { Eigen } \\
\text { value }\end{array}$ & $\begin{array}{c}\text { Percent of } \\
\text { variance }\end{array}$ & $\begin{array}{c}\text { Cumulative } \\
\text { percentage }\end{array}$ \\
\hline $\begin{array}{l}\text { Autumn } \\
\text { component 1 } \\
\text { component 2 }\end{array}$ & 2.54 & 50.75 & 50.75 \\
$\begin{array}{l}\text { Winter } \\
\text { component 1 }\end{array}$ & 1.11 & 22.10 & 72.85 \\
$\begin{array}{l}\text { component 2 } \\
\text { Spring }\end{array}$ & 2.06 & 41.26 & 41.26 \\
$\begin{array}{l}\text { component 1 } \\
\text { component 2 }\end{array}$ & 1.29 & 25.73 & 66.99 \\
$\begin{array}{l}\text { Summer } \\
\text { component 1 } \\
\text { component 2 }\end{array}$ & 1.95 & 38.95 & 38.95 \\
\hline & 1.25 & 25.07 & 62.02 \\
\hline
\end{tabular}

Consequently, assemblage position along that axis was rank correlated with salinity (Table 4). The second component extracted by PCA (Table 2 and 3) opposed $C$. labrosus to the remaining species and no significant rank correlation was found between assemblage position along this axis and salinity (Table 4). In autumn, the first component extracted by PCA (Tables 2 and 3) also opposed the species with a strong preference for freshwater sites $(M$. cephalus and $C$. labrosus) to those that avoided them (L. aurata, $L$. ramado and $L$. saliens), but assemblage position along this axis was not rank correlated with salinity (Table 4). The second axis was not correlated with salinity. No axis was correlated with salinity in winter.

\section{DISCUSSION}

The distribution of wild animals is ruled by a combination of environmental, biotic and stochastic factors. Assessing the relative importance of environmental and biotic factors is possible only if (1) the response curves relating the performance of the species to different environmental factors are known and (2) information about resource limitation is available. This was not true when the data reported here were collected, as the relationship between salinity and growth performance of the
TABLE 4. - Kendall's $\tau$ rank correlation between the position of assemblages along the axes (components) estracted by PCA and salinitity.* denotes a statistically significant correlation.

\begin{tabular}{lcc}
\hline & & Salinity \\
\hline \multirow{2}{*}{ Autumn } & Component 1 & $0.318(\mathrm{p}=0.147)$ \\
\multirow{3}{*}{ Winter } & Component 2 & $0.014(\mathrm{p}=0.950)$ \\
& Component 1 & $0.184(\mathrm{p}=0.389)$ \\
Spring & Component 2 & $0.290(\mathrm{p}=0.176)$ \\
Summer & Component 1 & $-0.421(\mathrm{p}=0.049)^{*}$ \\
& Component 2 & $0.316(\mathrm{p}=0.140)$ \\
& Component 1 & $-0.484(\mathrm{p}=0.023)^{*}$ \\
& Component 2 & $0.118(\mathrm{p}=0.581)$ \\
\hline
\end{tabular}

Mediterranean populations of the species considered here was ignored and information about whether they reach carrying capacity was also missing. Only once these gaps are partially filled (Cardona and Castelló, 1993; Gisbert et al., 1995; Cardona and Castelló-Orvay, 1997; Cardona 1999, 2000, 2001), can a good interpretation of the results be made. This explains the 15-year gap between sampling and the publication of the results.

Stepwise multiple linear regression is a popular method for analysing the relationship between species abundance and environmental parameters (Legendre and Legendre, 1998). Unfortunately, the curves that relate salinity and the growth performance of several grey mullet species are bell-shaped (Vallet et al.,, 1970; Cardona, 2000), indicating a non-monotonic relationship between abundance and salinity in the wild, which goes against one of the basic assumptions of the method. Therefore, an approach based on the procedure described by $\mathrm{Neu}$ et al., (1974) is preferred.

Comparing habitat availability and habitat use showed that the distribution of all grey mullet species in the estuaries of Minorca was strongly affected by salinity. M. cephalus and L. ramado are good osmoregulators, as they maintain a stable internal osmolality in a wide range of external salinity levels, including fresh water (Lasserre and Gallis, 1975; Nordlie and Lefler, 1975; Nordlie et al.,, 1982; Thomas, 1984; Kulikova et al.,, 1989). In

TABLE 3. - Component weights

\begin{tabular}{|c|c|c|c|c|c|c|c|c|}
\hline \multirow[b]{2}{*}{ Variable } & \multicolumn{2}{|c|}{ Autumn } & \multicolumn{2}{|c|}{ Winter } & \multicolumn{2}{|c|}{ Spring } & \multicolumn{2}{|c|}{ Summer } \\
\hline & co. 1 & co. 2 & co.1 & $\operatorname{co.} 2$ & co.1 & co. 2 & co. 1 & co. 2 \\
\hline CPUE of C. labrosus & -0.18 & 0.77 & 0.33 & -0.71 & -0.10 & -0.85 & 0.20 & -0.62 \\
\hline CPUE of L. aurata & 0.84 & -0.15 & 0.89 & 0.29 & -0.38 & 0.71 & -0.67 & 0.58 \\
\hline CPUE of L. ramado & 0.94 & 0.18 & 0.95 & 0.95 & 0.93 & 0.15 & 0.79 & 0.55 \\
\hline CPUE of L. saliens & 0.93 & -0.08 & -0.29 & -0.29 & -0.12 & 0.06 & -0.75 & 0.43 \\
\hline CPUE of $M$. cephalus & -0.25 & -0.68 & -0.41 & -0.22 & 0.96 & 0.06 & 0.81 & 0.49 \\
\hline
\end{tabular}


these two species, the cost of osmotic regulation is the lowest within the oligomesohaline range (Nordlie and Lefler, 1975; Cardona, 1994, 2000) and therefore growth is expected to be highest within that range, although experimental evidence is available only for M. cephalus (Cardona, 2000). Thus, it is not surprising to find that these two species showed a strong preference for sites with a salinity level under 15 , although adults may prefer more saline areas (Cardona, 2000; Chang et al., 2004). However, Chang et al., (2004) have revealed the existence of individual differences in the habitat preference of $M$. cephalus in Taiwan, as most specimens avoid freshwater sites throughout their life whereas others spend long periods there. Such variability may also be true for $L$. ramado, which is a species found over a wide range of salinity levels (Lafaille et al., 2002; Almeida, 2003). Indeed, Pombo et al., (2005) suggested that turbidity and temperature were the parameters that ruled the distribution of L. ramado in a Portuguese estuary, without any relevant role for salinity. However, these conclusions may be premature, as Pombo et al., (2005) combined samples collected monthly at different sites in two different years in a single analysis, thus confusing the factors that rule seasonal changes in abundance with those ruling spatial distribution in a given season.

The osmoregulatory strategy of $C$. labrosus differs from that reported above, as control of blood osmolality is poor and survival in freshwater for more than a few months is not possible (Lasserre and Gallis, 1975). However, the oxygen consumption and growth rate of this species are not affected by the salinity level within the oligoeuhaline range (Cardona and Castelló, 1993; Cardona and CastellóOrvay, 1997). Strikingly, C. labrosus strongly favoured year round sites with a salinity level lower than 15 , where no osmoregulatory advantage is expected. Furthermore, freshwater sites were also positively selected from autumn to spring, which goes against the predictions made based on laboratory experiments. Conversely, Almeida (2003) reported limited upstream penetration of C. labrosus in a Portuguese estuary when compared with that of $L$. ramado. The unexpected behaviour of $C$. labrosus in Minorca may be related to food availability, because the growth performance of C. labrosus improves in eutrophic sites (Walsh et al.,, 1994) and the trophic level of Mediterranean coastal lagoons depends on the freshwater input (Comin et al.,
1990). Actually, the most eutrophic coastal lagoons in Minorca are usually those with the lowest salinity (Cardona, 1994), which probably explains the above reported preference of C. labrosus for low salinity sites. C. labrosus might prevent osmoregulatory failure by moving between freshwater and brackish/euhaline sites while the mouths of the estuaries are open (autumn and winter). When they close, the specimens trapped in freshwater sites would die after a few months, which would explain why $C$. labrosus was found in freshwater sites in spring, but not in summer. Detailed information on the movements of this species within a single estuary is needed in order to test this hypothesis.

Information about the osmoregulatory strategies of $L$. aurata and $L$. saliens is scarce, but it suggests a different scenario. The growth performance and the osmotic maintenance cost of L. aurata are optimised in polyhaline water (Vallet et al.,, 1970; Shusmin, 1990), which explains why this species avoided sites with salinity levels under 15 all year round. There are no published data about the growth performance of L. saliens at different salinity levels, but oxygen consumption is independent of salinity within the oligoeuhaline range (Cardona, 1994) and this species can survive for several months in oligohaline but not in fresh water (Cardona, unpublished data). Thus, a free distribution in brackish and euhaline sites and strong avoidance of fresh water sites might be expected, although this is true only in autumn and winter. In spring and summer, sites with a salinity lower than 15 are avoided. These results are in sharp contrast with those reported by Pombo et al., (2005), who concluded that salinity did not contribute to explaining the variability observed in the abundance of L.aurata and L. saliens in a Portuguese estuary. Again, this is probably because Pombo et al., (2005) combined samples collected monthly at different sites in two different years in a single analysis, thus confusing the factors that rule seasonal changes in abundance, like temperature, with those ruling spatial distribution in a given season, like salinity.

Although salinity appears to be a major factor determining the distribution of the five grey mullet species in the estuaries of Minorca in May and July, this was not true in November and often in February. Inconsistency between habitat electivity and osmoregulatory skills was probably due to the combination of an off-shore reproductive migration (Brusle, 1981; Laffaille et al.,, 2002) and the reshuf- 
fling of part of the population among the estuaries once the sand bars that closed the mouths of the estuaries in spring and summer were removed by freshwater run-off in autumn.

The relevance of competition also deserves to be discussed. Competition at the detritivorous post-fry stage might explain the unexpected electivity pattern of C. labrosus from February to July, as it is complementary to that of L. saliens, the most abundant species on the island. However, evidence indicates that grey mullet are under carrying at the detritivorous post-fry stage in the largest estuary of the island (Cardona, 1999, 2001) and hence competitive exclusion seems unlikely. However, Gisbert et al. (1995) demonstrated that the zooplantophagous fry of $L$. aurata and M. cephalus are negatively affected by intense interspecific competition with $L$. ramado, whereas the zooplanktofagous fry of $L$. saliens and C. labrosus are unaffected. Grey mullet assemblages at the post-fry stage are expected to show the consequences of this juvenile competitive bottleneck and be dominated by $L$. saliens and C. labrosus, with $L$. ramado as a secondary species and L. aurata and $M$. cephalus occurring at much lower frequencies. This population make-up occurs in Minorca, which strongly supports the hypothesis that juvenile bottlenecks together with salinity are relevant for structuring grey mullet assemblages.

\section{ACKNOWLEDGEMENTS}

This study was supported by a grant from the Insitut Menorquí d'Estudis.

\section{REFERENCES}

Almeida, P.R. - 2003. Feeding ecology of Liza ramada (Risso, 1810) (Pisces, Mugilidae) in a south-western estuary of Portugal. Estuar. Coast. Shelf Sci., 57: 313-323.

Anonymous. - 1959. Symposium on the classification of brackish waters, Venice. Arch. Oceanogr. Limnol., 2 (suppl.): 1.

Baltz, B.M. - 1990. Autoecology. In: C.B. Schreck and P.B. Moyle (eds.), Methods for fish biology, pp. 585-608. American Fisheries Society, Bethesda

Ben Tuvia, A., E.B. Davidoff, J. Shapiro and D. Shefler. - 1992. Biology and management of lake Kinneret fisheries. Israeli. J. Aquaculture-Bamidgeh, 44: 48-65.

Blaber, S.J.M. - 1997. Fish and fisheries of tropical estuaries. Chapman and Hall, London. .

Brett, J.R. - 1979. Environmental facts and growth. In: W.S. Hoar and D.J. Randall (eds.), Fish physiology. Vol. I., pp. 1-89. Academic Press, New York.

Brusle, J. - 1981. Sexuality and biology of reproduction in grey mullets. In: O.H. Oren (ed.), Aquaculture of grey mullet, pp. 99154. Cambridge University Press, Cambridge.

Bulger, A.J., B.P. Hayden, M.E. Monaco, D.M. Nelson and M.G.
McCormick-Ray. - 1993. Biologically-based estuarine salinity zones derived from a multivariate analysis. Estuaries, 16: 311-322.

Cardona, L. - 1994. Estructura de las comunidades de mugílidos (Osteichthyes, Mugilidae) en ambientes estuáricos. Doctor of Science thesis, Univ. Barcelona.

Cardona, L. - 1999. Seasonal changes in the food quality, diel feeding rhythm and growth rate of juvenile leaping grey mullet Liza saliens. Aquat. Liv. Res, 12: 263-270.

Cardona, L. - 2000. Effects of salinity on the habitat selection and growth performance of Mediterranean flathead mullet Mugil cephalus. Estuar. Coast. Shelf Sci., 50: 727-737.

Cardona, L. - 2001. Non-competitive coexistence between Mediterranean grey mullet (Osteichthyes, Mugilidae): evidences from seasonal changes in food availability, niche breadth and trophic overlap. J. Fish Biol., 59: 729-744.

Cardona, L. and F. Castelló. - 1993. Weight loss of starved thick-lipped grey mullet (Chelon labrosus) yearlings at different salinities. Riv. Ital. Acquacolt., 28: 13-16.

Cardona, L. and F. Castelló-Orvay. - 1997. Effects of salinit0d grey mullet (Chelon labrosus) yearlings. Riv. Ital. Acquacolt., 32: $31-35$.

Cardona, L., P. Royo and X. Torras. - 2001. Effects of leaping grey mullet Liza saliens (Osteichthyes, Mugilidae) in the macrophyte beds of oligohaline Mediterranean coastal lagoons. Hydrobiologia, 462: 233-240.

Chang, C.W., Y. Iizuka and W.N. Tzeng. - 2004. Migratory environmental history of the grey mullet Mugil cephalus as revealed by otholit Sr:Ca ratios. Mar. Ecol. Prog. Ser., 269: 277-288.

Comín, F.A., M. Menéndez and J.R. Lucena. - 1990. Proposals for macrophyte restoration in eutrophic coastal lagoons. Hydrobiologia, 200/201: 427-436.

Cuadras, C.M. - 1983. Problemas de probabilidades y estadística. PPU, Barcelona.

De Angelis, R. - 1967. Oservazini sulle specie del genere Mugil segnalate lungo le coste del Mediterraneo. Bol. Pesca Pisc. Idrobiol, 22: 5-33.

Faouzi, H. - 1938. Quelques aspects de la biologie des muges en Egypte. Rapp. Comm. Int. Mer Médit., 11: 63-68.

Gisbert, E., L. Cardona and F. Castelló. - 1995. Competition between mullet fry. J. Fish Biol., 47: 414-420.

Heldt, H. - 1948. Contribution a l'étude de la biologie des muges des lacs tunisiens. Bull.Stat. Oceán. Salamô, 41: 1-50.

Kulikova, N.I., P.V. Shekk, L.I. Starushenko and V.I. Rudenko. 1989. Effect of salinity on resistance to low temperatures in the Black sea mullets during early ontogenesis. In: L.A. Dushkina (ed.), Early life history of mariculture species, pp. 81-102. Vniro, Moscow.

Laffaille, P., S. Brosse, E. Feunteun, A. Baisez, and J. - C. Lefeuvre. - 1998. Role of fish communities in particulate organic matter fluxes between salt marshes and coastal marine waters in the Mont Saint-Michel Bay. Hydrobiologia, 373/374: 121-133.

Laffaille, P., E. Feunteun, C. Lefebvre, A. Radureau, G. Sagan, G. and J. - C. Lefeuvre. - 2002. Can thin-lipped mullet exploit the primary and detritic production of European macrotidal salt marshes?. Estuar. Coast. Shelf Sci., 54: 729-736.

Lasserre, P. and J.L. Gallis. - 1975. Osmoregulation and differential penetration of two grey mullets, Chelon labrosus (Risso) and Liza ramada (Risso) in estuarine fish ponds. Aquaculture, 5: 323-344.

Legendre, P. and L. Legendre. - 1998. Numerical Ecology. Elsevier, Amsterdam.

McDowall, R.M. - 1988. Diadromy in fishes. Migrations between freshwater and marine environments. Croom Helm, London.

Neu, C.W., C.R. Byers and J.M. Peek. - 1974. A technique for analysis of utilization-availability data. J. Wild. Manag., 38: 541-545.

Nordlie, F.G. and C. Leffler. - 1975. Ionic regulation and the energetics of osmoregulation in Mugil cephalus Lin. Comp. Biochem. Physiol, 51A: 125-131.

Nordlie, F.G., N.A. Szelistowski and W.C. Nordlie. - 1982. Ontogenesis of osmotic regulation in the striped mullet, Mugil cephalus L. J. Fish Biol., 20: 79-86.

Paris, J. and J.P. Quignard. - 1971. La faune ichthyologique des étangs languedociens de Sète à Carnon (Ecologie, Éthologie). Vie Millieu, 22: 301-327. 
Perrow, M.R, I.M. Côté and M. Evans. - 1996. Fish. In: W.J. Sutherland (ed.), Ecological census techniques, pp 178-204. Cambridge University Press, Cambridge.

Pombo, L., M. Elliott and J.E. Rebelo. - 2005. Environmental influences on fish assemblage distribution of an estuarine coastal lagoon, Ria de Aveiro (Portugal). Sci. Mar., 69: 143-159.

Ranta, E., P. Lundberg and V. Kaitala. - 1999. Resource matching with limited knowledge. Oikos, 86: 383-385.

Ravagnan, G. - 1992. Vallicoltura integrata. Edagricole, Bologna.

Shusmin, A.G. - 1990. Effects of changes of salinity on survival, oxygen threshold and level of standard metabolism of young of the golden mullet (Liza aurata). J. Ichthyol., 30: 139-145.

Strauss, R.E. - 1979. Reliability estimates for Ivlev's electivity index, the forage ratio, and a proposed linear index of food selection. Trans. Am. Fish. Soc, 108: 344-352.

Thomas, P. - 1984. Influence of some environmental variables on the ascorbic acid status of mullet, Mugil cephalus L., tissues. I.
Effect of salinity, capture-stress and temperature. J. Fish Biol., 25: 711-720.

Torras, X., L. Cardona and E. Gisbert. - 2000. Cascading effects of flathead grey mullet Mugil cephalus of the ecosystem of eutrophic freshwater microcosmos. Hydrobiologia, 429: 49-57.

Vallet, F., J. Berhaut, C. Leray, B. Bonnet and P. Pic. - 1970. Preliminary experiments on the artificial feeding of Mulidae. Helgol. wiss. Meeresunters 20: 610-619.

Walsh, A., P. Reay, J. O'Halloran and K. Cahill. - 1994. The growth of grey mullet in a rural and urbanized Irish estuary. $J$. Fish Biol., 45: 889-897.

Wootton, R.J. - 1990. Ecology of teleost fishes. Chapman and Hall, London.

Scient. ed.: P. Oliver

Received September 1, 2005. Accepted February 20, 2006.

Published online July 10, 2006. 
